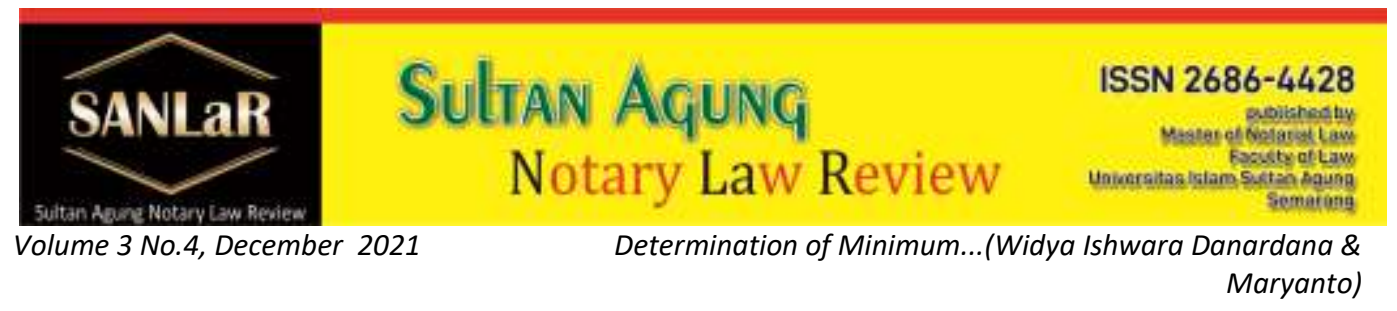

\title{
Determination of Minimum Rates for Notary Honorarium to Avoid Tariff War between Notaries
}

\author{
Widya Ishwara Danardana*) and Maryanto** \\ $\left.{ }^{*}\right)$ Faculty of Law, Universitas Islam Sultan Agung (UNISSULA) Semarang, E-mail: \\ donidanardana@gmail.com \\ $\left.{ }^{*}\right)$ Faculty of Law, Universitas Islam Sultan Agung (UNISSULA) Semarang, E-mail: \\ maryanto@unissula.ac.id
}

\begin{abstract}
The notary position is an institution created by the state. Notary as a position is a field of work created by legal rules for certain functions and is sustainable as a work environment. The existence of a notary as a state official who is authorized to make a legal product, namely an authentic deed, does not receive an honorarium from the state, therefore a notary is entitled to receive an honorarium for the legal services provided. Notaries receive an honorarium from the public for services in making an authentic deed. The honorarium is given to those who carry out their duties based on the laws and regulations, while the success fee is given to those who carry out the profession. Based on this description, This study aims to find out and analyze the basic regulatory considerations related to the amount of the Notary's honorarium in the Notary Position Act and the Notary Code of Ethics, analyze the formulation of the minimum amount of Notary honorarium arrangement, and find out the sanctions for notaries who violate the rules on the minimum rate of Notary honorarium. The research method in this thesis uses a sociological juridical approach with descriptive research specifications. Data sources and data collection methods used primary and secondary data which were analyzed qualitatively. The results of the study indicate that the basis for consideration of setting the minimum amount of notary honorarium in the Law on Notary Positions has not been determined regarding the minimum amount. Basically, the Law on Notary Positions only provides a maximum limit on the honorarium that can be withdrawn from transactions. Notaries have the right to determine their own values based on their considerations as long as they do not exceed the maximum provisions of the Law on Notary Positions. It is necessary to amend Article 36 of the Law on Notary Positions in order to mention the determination of the minimum honorarium limit determined by the notary position organization, so that the determination of the notary position professional organization has binding power based on the Notary Position Act.
\end{abstract}

Keywords: Arrangement; Formulation; Honorarium; Notary; Penalty; Public. 


\section{Introduction}

Notaries in their profession act as public servants as officials appointed by the government. In their service, the Notary is bound by the Position Regulations and the professional code of ethics as a notary. Notary is a legal profession and thus the notary profession is a noble profession (nobile officium). Referred to as a nobile officium because the notary profession is very closely related to humanity. ${ }^{1} \mathrm{~A}$ notary is a public official who is authorized to make an authentic deed as long as the making of a certain authentic deed is not reserved for other public officials. Making authentic deeds is required by legislation in order to create certainty, order and legal protection.

The notary position is an institution created by the state ${ }^{2}$. Placing a Notary as a position is a field of work or task that is deliberately created by the rule of law for certain purposes and functions (certain authorities) and is sustainable as a permanent work environment. The existence of a notary as a state official who is authorized to make a legal product, namely an authentic deed, does not receive an honorarium from the state, therefore a notary is entitled to receive an honorarium for legal services provided in accordance with his authority. ${ }^{3}$ Notaries receive an honorarium from the general public for services in making an authentic deed. The honorarium is only given to those who carry out their duties based on the laws and regulations, while the success fee is given to those who carry out the profession. ${ }^{4}$

In practice, the application of honorarium between one Notary to another is different, some apply the amount of honorarium in accordance with the provisions of Article 36 of Act No. 2 of 2014 concerning Amendments to Act No. 30 of 2004 concerning Notary Positions, but many Notaries apply below the standard provisions. Determining the honorarium for notary services below the standard which can lead to unfair business competition among notary partners, of course, creates its own problems, not only for fellow notaries but also for the notary concerned himself.

\footnotetext{
${ }^{1}$ Subekti dan Tjitrosudibio. (2009). Kitab Undang-Undang Hukum Perdata (Burgerlijk Wetboek). Jakarta: Pradnya Paramita, p. 1868

${ }^{2}$ A Chuasanga, Ong Argo Victoria. (2019). Legal Principles Under Criminal Law in Indonesia and Thailand, Jurnal Daulat Hukum, Vol 2, No 1 (2019) http://jurnal.unissula.ac.id/index.php/RH/article/view/4218 see also Deen, Thaufiq., Ong Argo Victoria \& Sumain. (2018). Public Notary Services In Malaysia. JURNAL AKTA: Vol. 5, No. 4, 10171026. Retrieved from http://jurnal.unissula.ac.id/index.php/akta/article/view/4135

${ }^{3}$ Salim HS. (2015). Teknik Pembuatan Akta Satu (Konsep Teoritis, Kewenangan Notaris, Bentuk dan Minuta Akta). Jakarta: RajaGrafindo Persada. p. 33

${ }^{4}$ Habib Adjie. (2008). Hukum Notaris Indonesia (Tafsir Tematik Terhadap Undang-Undang Nomor 30 Tahun 2004). Bandung: Refika Aditama. p.171
} 
One of the causes of unfair business competition among Notary partners is the determination of Notary service rates or honorariums below the standards set by law and the Code of Ethics ${ }^{5}$. This is very contrary to what is regulated in Act No. 2 of 2014 concerning Notary Positions and the Notary Code of Ethics, because Notaries are prohibited from making efforts to determine substandard tariff services to get as many clients as possible, but in practice there are notaries who do this.

Based on this, it is known the importance of setting a minimum rate of notary honorarium to avoid any unfair competition among other Notary colleagues because there are some Notaries who stick to the laws and the Notary Code of Ethics, especially in the war on honorarium rates

\section{Research Methods}

The approach method used in this research is the sociological juridical method, namely "a research conducted on the real situation of society or the community environment with the intent and purpose of finding facts, which then leads to identification (problem-identification) and ultimately leads to problem solving. ${ }^{6}$ In particular, the issue of setting the minimum rate for the notary's honorarium. The research specification used in this research is descriptive research. Descriptive research is research that only describes the phenomenon of an event or events that occur in the object of research which is then analyzed to obtain conclusions.

\section{Results and Discussion}

\subsection{Basic considerations for setting the minimum amount of notary honorarium in the Law on Notary Positions}

Notary is a profession related to individuals (individuals), notary professional organizations, society in general and the state, because the notary profession is directly related to all of them. Notaries while carrying out their duties, even though they are appointed and dismissed by the government, namely the Minister of Law and Human Rights of the Republic of Indonesia, but do not get a salary from the government or pension money from the government, so the honorarium received by the notary as the personal income of the notary

${ }^{5}$ Ong Argo Victoria, Ade Riusma Ariyana, Devina Arifani. (2020). Code of Ethics and Position of Notary in Indonesia. Sultan Agung Notary Law Review 2 (4), 397-407, http://lppmunissula.com/jurnal.unissula.ac.id/index.php/SANLaR/article/view/13536 see also Yaya Kareng, Ong Argo Victoria, R. Juli Moertiyono. (2019). How Notary's Service in Thailand. Sultan Agung Notary Law $\quad$ Review, $\quad 1 \quad$ 46-56, http://jurnal.unissula.ac.id/index.php/SANLaR/article/view/4435

${ }^{6}$ Soerjono Soekanto. (2007). Pengantar Penelitian Hukum. Jakarta: UII Press. p.10 
concerned while carrying out the notary profession. ${ }^{7}$ The law only regulates the maximum tariff for Notary services or the honorarium that each Notary has the right to receive. ${ }^{8}$ The notary is obliged to provide the same legal action, because the deed made by the notary concerned will not make any difference, whether he is able to pay the honorarium or the free one.

\section{a. According to the Law on Notary Position}

The notary's obligations are specifically and detailed in the sound of article 16 paragraph (1) letter a to letter $n$. Meanwhile, the right of a Notary is to receive compensation from his work, in the form of an honorarium or fee. Honor received by a notary after carrying out his duties.

Notaries have the right to collect an honorarium or compensation in the form of money, the amount of which has been stated in Article 36 of the Law on Notary Positions, as follows:

1) Notaries are entitled to receive an honorarium for legal services provided in accordance with their authority.

2) The amount of honorarium received by the Notary is based on the economic value and sociological value of each deed made.

3) The economic value as referred to in paragraph (2) is determined from the object of each deed as follows:

a) Up to IDR $100,000,000.00$ (one hundred million rupiah) or the equivalent of grams of gold at that time, the maximum honorarium received was 2.5\% (two point five percent).

b) Above IDR $100,000,000.00$ (one hundred million rupiah) up to IDR $1,000,000,000.00$ (one billion rupiah) up to $1.5 \%$ (one point five percent).

c) Above IDR 1,000,000,000.00 (one billion rupiah) honorarium received is based on an agreement between the Notary and the Parties, but does not exceed $1 \%$ (one percent) of the object for which the deed is made.

The sociological value is determined based on the social function of the object of each deed with a maximum honorarium of IDR 5,000,000.00 (five million rupiah)

The consideration of determining the amount of honorarium depends on an assessment of the economic and social value of a transaction. In the Law on Notary Positions it cannot simply be practiced without looking at other aspects. The custom among Notaries is that there is a negotiation to determine the tariff agreed by both parties.

\footnotetext{
${ }^{7}$ Habib, Adjie. (2008). Hukum Notaris Indonesia Tafsir Tematik Terhadap UU No. 30 Tahun 2004 Tentang Jabatan Notari. Bandung: Rafika Aditama. p. 108

${ }^{8}$ Harlien, Budiono. (2018). Kumpulan Tulisan Hukum Perdata. Bandung: Citra Aditya Bakti. p. 166
} 


\section{b. According to the Notary Code of Ethics}

The Notary Code of Conduct was established in January 2005, drawn up by the Indonesian Notary Association, in Bandung. The Notary Code of Ethics is made so that the Notary in carrying out his duties must have ethics in accordance with the Notary Code of Ethics that has been made. This is very important in maintaining the attitude and behavior of the Notary. The word "ethics" is etymologically derived from the Greek word "ethos". The literal meaning of "ethics" is defined as "customs", "character", or "human behavior", of course, as a term that is quite widely used in everyday life, the word "ethics" has a broader meaning than just an etymological meaning. ${ }^{9}$

Based on the notion of ethics that has been formulated in Big Dictionary of Indonesia, published by the Ministry of Education and Culture in 1998, it can be formulated that the notion of ethics is:

1) Ethics means a collection of moral principles or values.

2) Moral values and norms held by a person or group of people in society to regulate their behavior.

3) Ethics as the science of good and bad ${ }^{10}$

Systematically, ethics are divided into general ethics and special ethics. Special ethics are further divided into individual ethics and social ethics. ${ }^{11}$ General ethics discusses the basic principles of morals, such as the meaning of ethics, the function of ethics, issues of freedom, responsibility and the role of conscience. Special ethics apply the basic principles of morality to each area of human life. The basic question of special ethics is how should act in the field concerned, or how the field needs to be organized in order to support the achievement of human goodness as a human being. ${ }^{12}$

In the Indonesian Notary Code of Ethics, several regulations that must be adhered to by a Notary other than the Law on Notary Positions have been set, namely: ${ }^{13}$

1) Notary Personality, this is explained to:

\footnotetext{
${ }^{9}$ Refik, Issa, Beekum. (2004). Etika Bisnis Islam. Yogyakarta: Pustaka Pelajar. p. 3

${ }^{10}$ E.Y, Kanter. (2001). Etika Profesi Hukum (Sebuah Pendekatan Religius). Jakarta: Storia Grafika. p. 12

${ }^{11}$ Franz, Magnis, Suseno. (1987). Etika Politik. Jakarta: Gramedia Pustaka Utama. p. 13

${ }^{12}$ C.S.T. Kansil dan Christine ST. Kansil, (2006). Pokok - Pokok Etika Profesi Hukum. Jakarta: Pradnya Paramitha. p. 4

${ }^{13}$ Abdul, Kadir, Muhammad. (2006). Etika Profesi Hukum. Bandung: Citra Adytia Bakti. p. 50
} 
a) In carrying out his duties, he is imbued with Pancasila, is aware of, and obeys the law, notary office regulations, oath of office, Notary Code of Ethics and good Indonesian language.

b) Have professional behavior and participate in national development, especially in the field of law.

c) Have a good personality and uphold the dignity and honor of a Notary, both inside and outside the duties of his position.

2) In carrying out their duties, the Notary must:

a) Realizing their obligations, working independently, being honest and impartial and with a full sense of responsibility.

b) Using one office in accordance with what is stipulated by the Notary Position Act, and not opening branch and representative offices and not using intermediaries.

c) Do not use promotional mass media.

3) The Notary's relationship with the client must be based on:

a) Notaries provide services to people who need their services as well as possible.

b) Notaries provide legal counseling to achieve high legal awareness, so that community members are aware of their rights and obligations.

c) Notaries must provide services to underprivileged members of the community.

4) Notaries with fellow notaries, must:

a) Respect in a family atmosphere.

b) Do not commit acts or competition that is detrimental to others.

c) Protect and defend each other's honor and the Notary Corps on the basis of solidarity and constructive help.

\subsection{The Ideal Minimum Honorarium Arrangement Formulation for Notaries}

The arrangement regarding honorarium or remuneration for Notary services in the case of making an authentic deed is regulated in Article 36 of the Law on Notary Positions, that:

1) Notaries are entitled to receive an honorarium for legal services provided in accordance with their authority.

2) The amount of honorarium received by the Notary is based on the economic value and sociological value of each deed made. 
3) The economic value as referred to in paragraph (2) is determined from the object of each deed as follows:

a) Up to IDR $100,000,000.00$ (one hundred million rupiah) or the equivalent of grams of gold at that time, the maximum honorarium received was $2.5 \%$ (two point five percent).

b) Above IDR 100,000,000.00 (one hundred million rupiah) up to IDR $1,000,000,000.00$ (one billion rupiah) up to $1.5 \%$ (one point five percent).

c) Above IDR 1,000,000,000.00 (one billion rupiah) honorarium received is based on an agreement between the Notary and the Parties, but does not exceed $1 \%$ (one percent) of the object for which the deed is made.

4) The sociological value is determined based on the social function of the object of each deed with a maximum honorarium of IDR 5,000,000.00 (five million rupiah)

The code of ethics aims to prevent dishonest competition between Notaries. It is very important to make strict rules regarding the determination of the minimum standard of the Notary service rate so that it can be used as a reference for every Notary in setting the lowest rate, which is set to his client in making a deed in order to create a uniform rate for each same transaction, so that there is a very significant tariff difference between one Notary to another.

The public can compare Notaries in terms of the honorarium, which is determined so that it will not lead to dishonest competition, but the determination of the minimum rate with the exception of poor people who can't afford it, so that all people can be treated equally before the law and can use the services of a Notary.

Determination of notary organization regulations, in each region the minimum tariff for notary services is set, so that there is justice for notaries in receiving notary service rates. In the organizational regulations, sanctions are made for violations of the provisions of the minimum tariff standard for Notary services that apply in each region.

In practice, the low honorarium received by a Notary is the result of negotiations between the Notary and the client. This is actually legitimate, but it seems inappropriate. Therefore, the professional services of a Notary are treated like merchandise, so the price paid is the result of bargaining. Basically, Notaries who return a list of statements stating that they are willing to comply with the existing regulations, but the problem is that according to them, the existing rules 
are not clear and have no firmness. In the Law on Notary Positions Number 2 of 2014 the matter of honorarium is also regulated in article 36 , namely: ${ }^{14}$

Paragraph (1) A notary has the right to receive an honorarium received by a notary based on the economic value and sociological value of each deed he makes.

Paragraph (2) The amount of honorarium received by a notary is based on the economic value and sociological value of each deed he makes.

\subsection{Sanctions for Notaries who violate the rules for the minimum rate of Notary honorarium}

Sanctions are a means of coercion, in addition to the law, also to comply with the provisions specified in the regulations or agreements. Sanctions are also interpreted as a means of coercion as a law if they do not obey the agreement. According to Philipus M, Hadjon, sanctions are public legal power tools used by authorities as a reaction to non-compliance with administrative legal norms. Thus the elements of sanctions are:
a. As a tool of power;
b. Public law nature;
c. Used by rulers;
d. As a reaction to disobedience.

Sanctions that are intended for Notaries are made so that Notaries can carry out their work and duties correctly and honestly so that an authentic deed which is a Notary product is expected to provide legal protection and certainty to the parties who have the deed and have an interest in the authentic deed. ${ }^{15}$

Sanctions imposed on a Notary as a person are regulated in Article 85 of the Law which reads: ${ }^{16}$

Violation of the provisions as referred to in Article 7, Article 16 paragraph (1) letter a, Article 16 paragraph (1) letter b, Article 16 paragraph (1) letter c, Article 16 paragraph (1) letter $d$, Article 16 paragraph (1) letter e, Article 16 paragraph (1) letter f, Article 16 paragraph (1) letter g, Article 16 paragraph (1) letter $h$, Article 16 paragraph (1) letter i, Article 16 paragraph (1) letter j, Article 16

\footnotetext{
${ }^{14}$ Act No. 2 of 2014 on amendments to Act No. 30 of 2004 concerning the Position of Notary ${ }^{15}$ Habib.Adjie. (2015). Penafsiran Tematik Hukum Notaris Indonesia Berdasarkan Undang Undang Nomor 2 Tahun 2014 Tentang Perubahan Atas Undang - Undang Nomor 30 Tahun 2004 Tentang Jabatan Notaris. Bandung: PT Refika Aditama. p. 57

${ }^{16}$ Yuniati, S. (2017). Mekanisme Pemberian Sanksi Terhadap Notaris Yang Melakukan Pelanggaran Kode Etik Jabatan Notaris. Jurnal Akta, 4(4). p. 585-590
} 
paragraph (1) letter k, Article 17, Article 20, Article 27, Article 32, Article 37, Article 54, Article 58, Article 59, and/or Article 63, may be subject to sanctions in the form of:
a. verbal reprimand;
b. written warning;
c. Temporary suspension;
d. Dismissal with honor;
e. Disrespectful dismissal.

The sanctions contained in the article apply in stages, starting from an oral warning to dishonorable dismissal. The reprimand, both oral and written, is only an initial stage.

To enter into the actual form of sanctions, namely temporary dismissal with respect and dishonorable dismissal. Article 9 paragraph (1) of Act No. 2 of 2014 concerning amendments to Act No. 30 of 2004 concerning Notary Positions determines the reasons for notary being terminated temporarily from his position because he is in the process of bankruptcy or postponement of debt payment obligations, is under pardon, committed a disgraceful act, violated the obligations and prohibitions of the position. Meanwhile, the reasons why a Notary can be dismissed from his position with respect are described in Article 8 paragraph (1) of Act No. 30 of 2004 concerning the Position of a Notary, namely:

a. Die;

b. Has reached the age of 65 (sixty five) years;

c. own request;

d. Incapable spiritually and/or physically to carry out the duties of a Notary position continuously for more than 3 (three) years; or

e. Concurrent positions as referred to in Article 3 letter $\mathrm{g}$.

The regulation of sanctions in Articles 84 and 85 of the Law on Notary Positions as mentioned above, if examined carefully, does not yet summarize all the sanctions contained in the Law on Notary Positions. It turns out that there are still articles scattered in the Law on Notary Positions that regulate sanctions, including:

a. Article 8 paragraph (1) letter e of the Law on Notary Positions which is a provision for sanctions if Article 3 letter $g$ of the Law on Notary Positions is violated.

b. Article 16 paragraph (8) of the Law on the Position of Notary which is a sanction if Article 16 (1) letter $i$ and paragraph (7) of the Law on the Position of Notary are violated. 
c. Article 41 of the Law on Notary Positions is an article which is a provision for sanctions if Articles 39 and 40 of the Law on Notary Positions are violated.

d. Article 52 paragraph (3) of the Notary Position Act is a provision for sanctions if Article 52 paragraph (1) of the Notary Position Law is violated.

e. Then there are provisions or articles of the Notary Position Act which are not subject to sanctions, including: Article 11 paragraph (1), Article 16 paragraph (1) letter m, Article 36, and Article 53 of the Notary Position Act.

\section{Conclusion}

The basis of consideration for setting the minimum amount of notary honorarium in the Law on Notary Positions has not yet been determined regarding the minimum amount. The magnitude of the provisions contained in the Law on Notary Positions makes most clients object, so special policies regarding the collection of honoraria are treated. Basically, the Law on Notary Positions only provides a maximum limit of the honorarium that can be withdrawn from transactions. Notaries have the right to determine their own economic value based on their considerations as long as it does not exceed the maximum provisions of the Law on Notary Positions. Thus the consideration of determining the amount of honorarium depends on the assessment of the economic and social value of a transaction. The provisions in the Law on Notary Positions cannot simply be put into practice without looking at other aspects. The formulation of the ideal minimum amount of honorarium for a notary. It is better if the determination of the honorarium is regulated in the notary position organization regulations, where the enactment of the stipulation of the notary organization regulations in each region is determined what the minimum tariff for notary services is, so as to create justice for the notary in receiving the notary service rate. Then in the organizational regulations, sanctions are made for violations of the provisions of the minimum tariff standard for notary services that apply in each region. The need for amendments to Article 36 of the Law on Notary Positions to also mention the determination of the minimum honorarium limit determined by the notary position organization. Sanctions that can be imposed on Notaries who do not apply the honorarium in accordance with Act No. 2 of 2014 concerning Amendments to Act No. 30 of 2004 concerning the Position of a Notary, are not further regulated in Act No. 2 of 2014 concerning Amendments to Laws Number 30 of 2014 concerning Notary Positions, however, sanctions that can be imposed on Notaries who apply honoraria are only regulated in Article 6 of the Notary Code of Ethics.

\section{Reference}

Journals: 
[1] A Chuasanga, Ong Argo Victoria. (2019). Legal Principles Under Criminal Law in Indonesia and Thailand, Jurnal Daulat Hukum, Vol 2, No 1 (2019) http://jurnal.unissula.ac.id/index.php/RH/article/view/4218

[2] Deen, Thaufiq., Ong Argo Victoria \& Sumain. (2018). Public Notary Services In Malaysia. JURNAL AKTA: Vol. 5, No. 4, 1017-1026. Retrieved from http://jurnal.unissula.ac.id/index.php/akta/article/view/4135

[3] Ong Argo Victoria, Ade Riusma Ariyana, Devina Arifani. (2020). Code of Ethics and Position of Notary in Indonesia. Sultan Agung Notary Law $\begin{array}{llll}\text { Review } & 2 & (4), \quad 397-407, \quad \text { http://lppm- }\end{array}$ unissula.com/jurnal.unissula.ac.id/index.php/SANLaR/article/view/13536

[4] Yaya Kareng, Ong Argo Victoria, R. Juli Moertiyono. (2019). How Notary's Service in Thailand. Sultan Agung Notary Law Review, 1 (1), 46-56, http://jurnal.unissula.ac.id/index.php/SANLaR/article/view/4435

[5] Yuniati, S. (2017). Mekanisme Pemberian Sanksi Terhadap Notaris Yang Melakukan Pelanggaran Kode Etik Jabatan Notaris. Jurnal Akta, 4(4).

Books:

[1] Abdul, Kadir, Muhammad. (2006). Etika Profesi Hukum. Bandung: Citra Adytia Bakti.

[2] C.S.T. Kansil dan Christine ST. Kansil, (2006). Pokok - Pokok Etika Profesi Hukum. Jakarta: Pradnya Paramitha.

[3] E.Y, Kanter. (2001). Etika Profesi Hukum (Sebuah Pendekatan Religius). Jakarta: Storia Grafika.

[4] Franz, Magnis, Suseno. (1987). Etika Politik. Jakarta: Gramedia Pustaka Utama.

[5] Habib Adjie. (2008). Hukum Notaris Indonesia (Tafsir Tematik Terhadap Undang-Undang Nomor 30 Tahun 2004). Bandung: Refika Aditama.

[6] Habib, Adjie. (2008). Hukum Notaris Indonesia Tafsir Tematik Terhadap UU No. 30 Tahun 2004 Tentang Jabatan Notari. Bandung: Rafika Aditama.

[7] Habib.Adjie. (2015). Penafsiran Tematik Hukum Notaris Indonesia Berdasarkan Undang - Undang Nomor 2 Tahun 2014 Tentang Perubahan Atas Undang - Undang Nomor 30 Tahun 2004 Tentang Jabatan Notaris. Bandung: PT Refika Aditama.

[8] Harlien, Budiono. (2018). Kumpulan Tulisan Hukum Perdata. Bandung: Citra Aditya Bakti.

[9] Refik, Issa, Beekum. (2004). Etika Bisnis Islam. Yogyakarta: Pustaka Pelajar.

[10] Salim HS. (2015). Teknik Pembuatan Akta Satu (Konsep Teoritis, Kewenangan Notaris, Bentuk dan Minuta Akta). Jakarta: RajaGrafindo Persada. 
[11] Soerjono Soekanto. (2007). Pengantar Penelitian Hukum. Jakarta: UII Press.

[12] Subekti dan Tjitrosudibio. (2009). Kitab Undang-Undang Hukum Perdata (Burgerlijk Wetboek). Jakarta: Pradnya Paramita.

Regulation:

Act No. 2 of 2014 on amendments to Act No. 30 of 2004 concerning the Position of a Notary. 